\title{
METHODOLOGY OF HISTORICAL UNDERGROUND OBJECTS INVENTORY SURVEYS - CONTRIBUTION
}

\author{
${ }^{1}$ AGH University of Science and Technology, Poland
}

Keywords: survey, underground inventory, TLS, historical underground objects

\begin{abstract}
Geodetic surveys are used in an inventory of a lot of industries, including documentary of historic objects. One of the hardest historic objects that need to be inventoried are underground ones. Observations of rock mass movements and their consequences are very crucial issues, especially in the aspect of protection of historical objects, therefore it is needed to implement special methods (especially non-invasive) and specialist protection. In Poland there are few underground UNESCO mines and a lot of other objects of historical importance, for example built by Nazi Germans. Authors describe the following measurement methods: tacheometric surveys, terrestrial laser scanning (TLS), leveling and as supporting methods: Airplane Laser Scanning (and its product: LIDAR), Global Positioning System and satellite images or geophysics methods.

There were inventory surveys conducted in Project Riese (German form - Giant) in Góry Sowie, Central Sudetes (Poland), is the biggest mining and building project of Second World War Germany. Until today, due to the lack of documentation, the purpose of these construction is uncertain. There are only hypothesis rather than facts. Currently, six underground complexesOsówka, Włodarz, Soboń, Rzeczka, Jugowice, Gontowa, Książ Castle are discovered in the area of Góry Sowie. There are some speculations that all complexes were supposed to be combined. Some of the researchers of Góry Sowie secrets claim that kilometers of tunnels are still able to be discovered in the future. During the inventory the combination of classical measurements technologies and modern surveys methods were used - terrestrial laser scanner, tacheometry and GNSS measurements. Authors used collected data to analyze geometrical relations between objects Complex underground and ground of Osówka. This allowed to verify location of objects in relations to each other which was not previously presented in research. Many sections and profiles of excavations, sketches and maps were made.
\end{abstract}

\section{METODY INWENTARYZACJI HISTORYCZNYCH OBIEKTÓW PODZIEMNYCH}

Słowa kluczowe: pomiary inwentaryzacyjne, podziemne obiekty historyczne, ALS, dziedzictwo kulturowe

\section{Streszczenie}

Procesy zachodzące w górotworze wymagają, aby każdy podziemny obiekt podlegał inwentaryzacji i kontroli. Na szczególną uwagę zasługują przede wszystkim historyczne i zabytkowe obiekty wydrążone pod ziemią, które powinny być objęte ochroną i działaniami umożliwiającymi ich rewitalizację, czy udostępnienie dla turystów. Ochrona tego typu zabytków wymusza kompleksowe podejście do problemów ich zabezpieczania i stosowanie różnego rodzaju metod inwentaryzacji, przede wszystkim ze względu na ich zazwyczaj i niepowtarzalny charakter. W Polsce znajduje się kilka podziemnych kopalni wpisanych na listę Światowego Dziedzictwa UNESCO oraz obiektów ważnych pod względem historycznym, np. wybudowanych przez Niemców w czasie drugiej wojny światowej.

Proces inwentaryzacyjny takich obiektów opiera się na kilku ważnych aspektach, m.in.: rozpoznaniu warunków geotechnicznych i hydrogeologicznych otaczającego obiekt górotworu, badaniu konwergencji i deformacji, przy dokładnej analizie zależności geometrycznych obiektu. Inwentaryzacja oraz badania deformacji górotworu i powierzchni terenu prowadzone są na 
podstawie obserwacji wykonanych metodami geodezyjnymi. Podstawowymi pomiarami stosowanymi pod ziemią są: precyzyjna niwelacja geometryczna oraz metody precyzyjnej poligonizacji, zazwyczaj wzmacniane pomiarem giroskopowym. Ważnym aspektem jest wykorzystanie technologii naziemnego skaningu laserowego $\mathrm{w}$ inwentaryzacji obiektów podziemnych oraz pomiary wspomagające tę technologie, takie jak: ALS, statyczne pomiary GNSS, klasyczna tachimetria czy badania geofizyczne.

Dzięki pomiarom inwentaryzacyjnym wizualizacji podziemnych obiektów kompleksu „Riese” w Górach Sowich, opartych głównie na technologii skaningu laserowego, zebrano potężny materiał do analizy. Pomiary zostały wykonane zarówno w sztolniach ogólnodostępnych lub częściowo dostępnych dla ruchu turystycznego (Osówka, Rzeczka, podziemia Zamku Książ), jak i niedostępnych (Jugowice, Soboń). W ramach prac kameralnych dokonano przede wszystkim rewizji zależności geometrycznych wyrobisk w Podziemnym Mieście Osówka (największym z kompleksów Riese) oraz okolicznych obiektach naziemnych, stworzono liczne plany, rzuty i przekroje każdego z inwentaryzowanych obiektów, które porównano i zweryfikowano z materiałami archiwalnymi. Ponadto stworzono trójwymiarowe modele Kasyna oraz Siłowni (naziemne obiekty Osówki).

\section{INTRODUCTION}

The stability of underground historical objects is influenced and threatened by various factors. In Poland, depending on the geographical location and local rock mass structure, these may be further threats:
- Tectonic or rock mass movements occur in the area of the Sudeten foothills and the Carpathians, including Salt mines in Wieliczka and Bochnia (both on the UNSESCO World Heritage List) and the Riese Complex in the Sowie Mountains [16], [17].

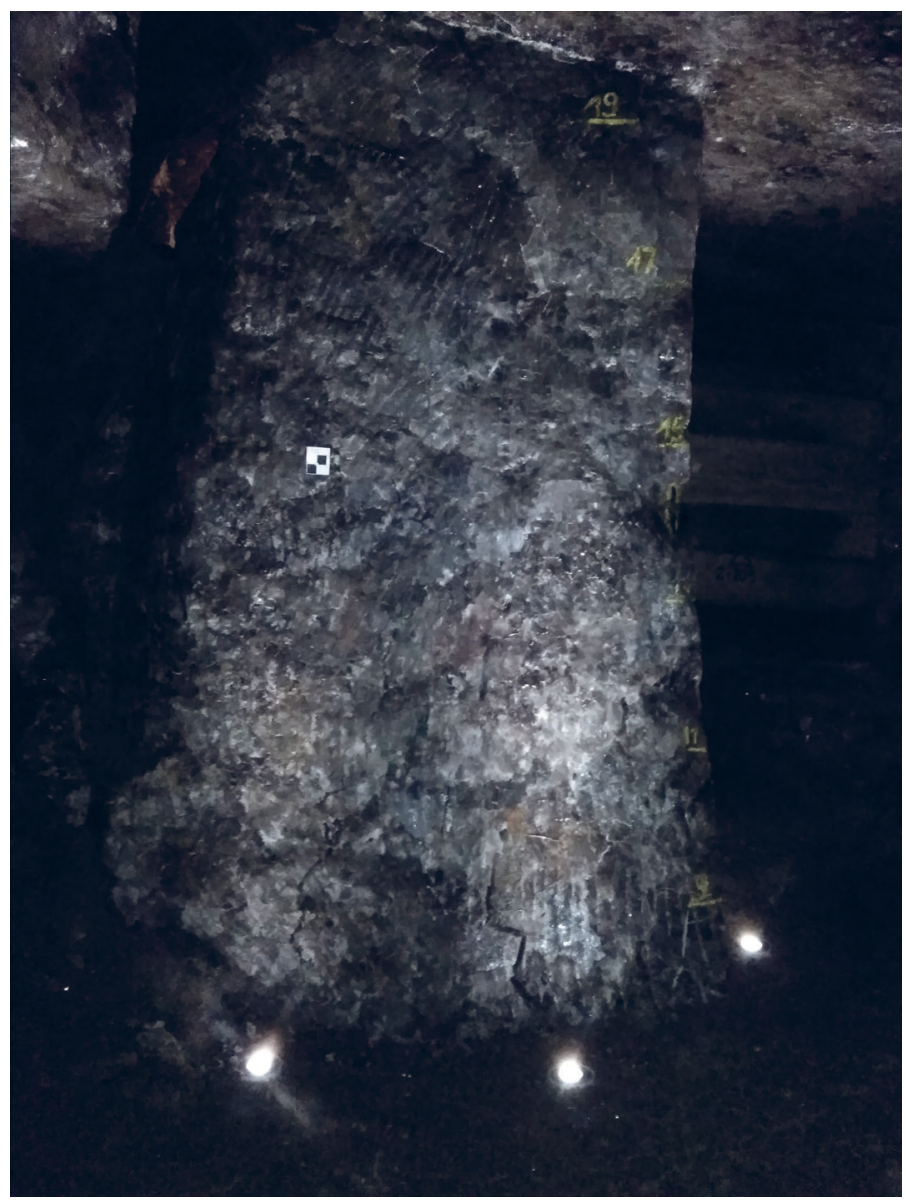

Fig. 1. Cracks of the pillar in the Inanimate Nature Reserve Crystal Grottoes in Salt Mine Wieliczka, authors' own archive Rys. 1. Pęknięcia filaru w rezerwacie przyrody Groty Kryształowe w Kopalni Soli w Wieliczce, źródło: archiwum autorów 
- Anthropological movements of the rock mass resulting from nearby or undocumented, old and shallow mining activities. In this group, one should mention the silver mine on the UNESCO list in Tarnowskie Góry, once again Salt Mines in Wieliczka and Bochnia and outside the list, among others Guido mine with the Adit of Luiza in Zabrze or the Old Mine Museum in Wałbrzych. This unique threat to objects occurs in many places in southern Poland, it is also felt in old cities, where only years later inventoried complex underground systems, such as remnants of chalk mines in Chełm or unrelated to mining, for example under the Krakow market or in Sandomierz.

- Water, especially dangerous for historical objects in salt and karst excavations. In this group there are once again the Salt Mines in Wieliczka and Bochnia, as well as in Kłodawa. Salt works, usually surrounded by a gypsum or anhydrite cap, are exposed to water as a result of karst phenomena, followed by uncontrolled leaching and leaving voids in the rock mass. Examples of disasters associated with water in saltworks may be the water leakage to the Transverse Salt Mine in Wieliczka in 1992 [11] or the complete collapse of the gypsum and salt mine in the Wapno village in 1977.
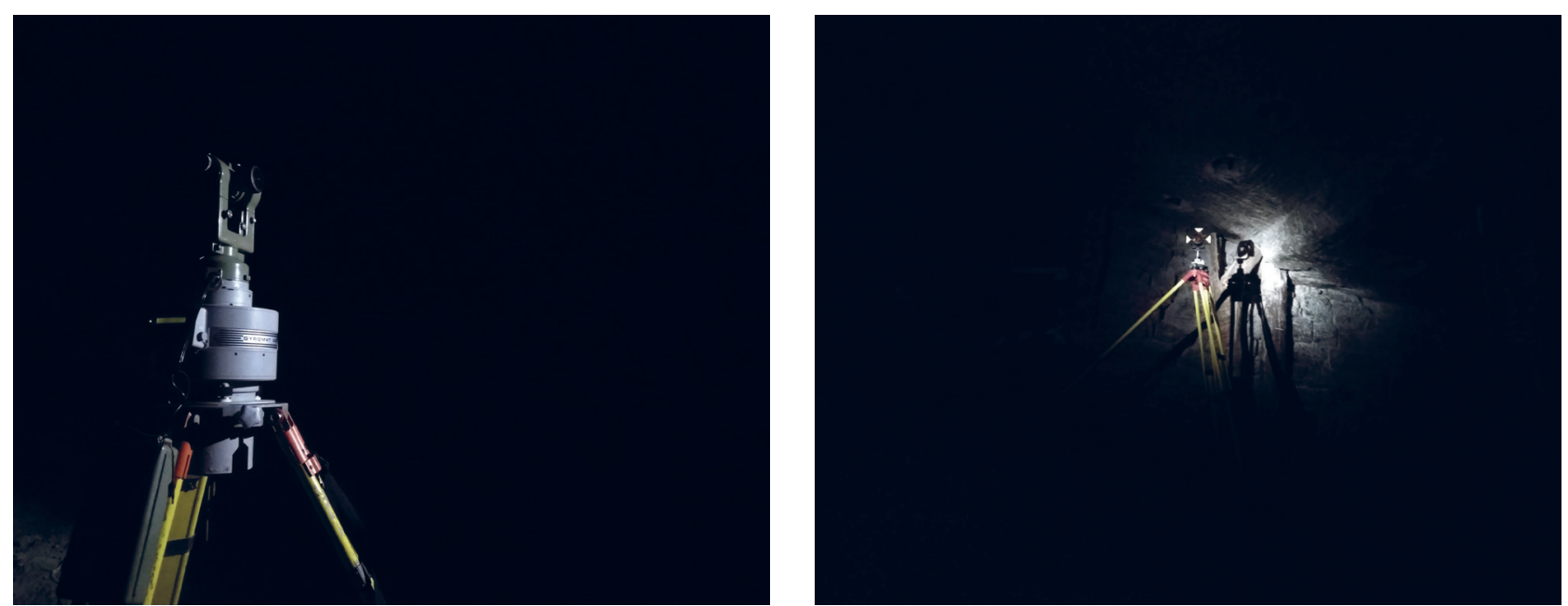

Fig. 2. Underground gyroscopic measurement (Gyromat 2000) and polygonisation, Crystal Grottoes in Salt Mine Wieliczka, authors' own archive

Rys. 2. Podziemne pomiary giroskopowe (Gyromat 2000) oraz poligonizacja, Groty Kryształowe w Kopalni Soli „Wieliczka”, źródło: archiwum autorów 


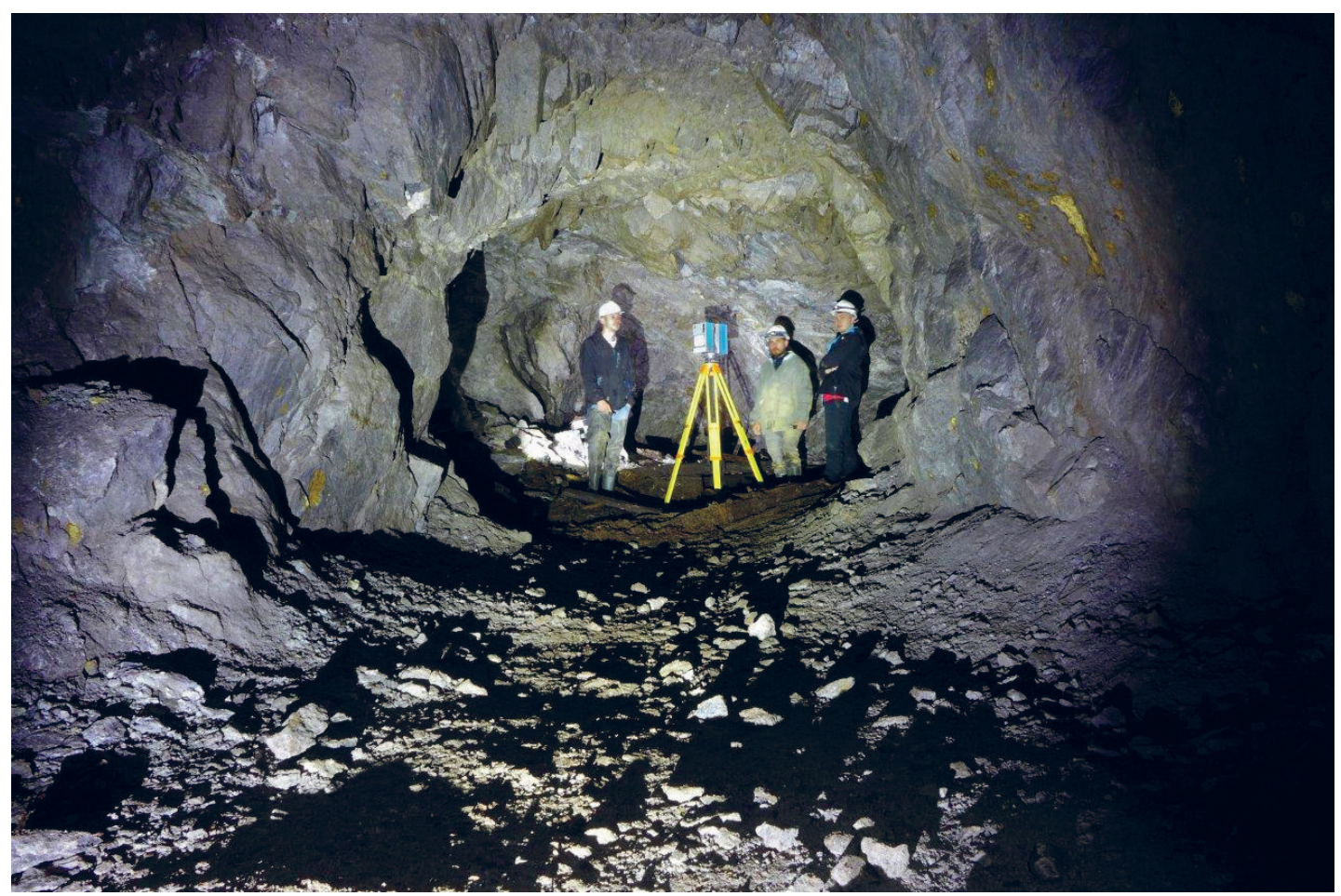

Fig. 3. TLS in adits of Riese, photo J. Cera

Rys. 3. Wykorzystanie technologii naziemnego skaningu laserowego w Riese, fot. J. Cera

Inventory and study of deformation process in rock mass and of terrain surface are carried out based on observations made with geodetic or geophysics methods [13], [14]. The basic measurements used underground are precise geometric levelling and methods of precise polygonization usually enhanced by gyroscopic measurement (Fig. 2) [9]. These methods allow for precise determination of vertical and horizontal displacements in underground objects. The usage of gyroscopic measurements increases the accuracy of determining horizontal displacements. It also allows direct determination of absolute azimuth changes at selected points of the polygon, which may indicate movements of the surrounding rock mass [10].

Currently, terrestrial laser scanning technology (TLS) is more common in usage during the inventory of underground objects [12], [15] (Fig. 3). Laser scanners provide a huge amount of data in form of point cloud (from several hundred to several hundred million points with known $\mathrm{X}, \mathrm{Y}, \mathrm{Z}$ coordinates in local coordinate system). Moreover, surveys with the usage of the laser scanner take place automatically and allow to perform other geodetic works during the measurement. What is important underground - these technology does not require good lighting and ensures high safety during surveys. Post-processing of obtained data allows obtaining a quasi-continuous model of the object and performing many spatial analyses. Additionally, by performing cyclic measurements, enables to receive information about the value of volume convergence and dangerous changes in the surroundings of the inventoried [15].

Supporting measurements for inventory of historical underground objects with TLS technology are GNSS surveys conducted on the surface. For making a point cloud of underground object a spatial unit in the global system, GNSS measurements are carried out with a differential static method. For this purpose, a network of geodetic control points at a short distance from the entrances to the inventoried objects on the surface is created. In consequence, the determined in this way coordinates enable positioning the point cloud in a global reference system (the process of assigning the georeference).

During the analysing the surroundings of underground objects, especially the surface above them, the data obtained with aerial laser scanning (ALS) is use- 
ful [1]. ALS is mainly used to acquire a precise three-dimensional model of the terrain surface - DTM LIDAR point clouds obtained in different periods allow creating historical three-dimensional terrain models in order to conduct a comparative analysis of surface changes, map complex areas and help to highlight objects hidden in the landscape [5]. The process of converting a point cloud to a terrain model is complex and largely automated [6]. LIDAR (Light Detection and Ranging) data gives the ability to extract a specific field layer to perform suitable analyses. Using this division of data into layers, it is possible to distinguish from them points classified as the "ground" in the area of interest. To create DTM, the form of the polygon mesh is used most frequently. The example of used DTM visualization is shaded relief (also called hill-shading), which simulates the cast shadow thrown upon the represented surface. It helps to visualize even small height variations and terrain discontinuities. ALS data can be combined with the results of TLS measurements. This can be done on the basis of georeference or when more precision is required, through transformation.

Determining the state of the rock mass over the underground voids is possible with gravimetric measurements, which allow defining the current characteristics and parameters of the rock mass. Detailed data about relaxation and cracks that occur in the surroundings of the underground objects, and particularly above them, as well as detecting underground cavities can be ob- tained by using the non-invasive microgravimetric method [14]. Because the anthropogenic voids were usually drilled in terrestrially diversified areas, it is necessary to implement the topographic gravity to calculations. For this purpose, geodetic measurements aimed at creating DTM and determining the spatial shape of underground voids are also necessary. The whole comprehensive measurement results allow estimating the stability of the examined underground objects.

\section{RESEARCH AREA - RIESE COMPLEX}

The example of usage of almost all mentioned technics could be Riese Complex where authors took part in surveys. During the Second World War, Nazi Germany located strategic buildings in safe regions, including the Sudetes. Infrastructure protection plans involved the relocation of weapon factories and the construction of anti-aircraft shelters for civil servants to underground bunkers. Riese Complex (German for "giant") is the biggest underground construction project of Nazi Germany in 1943-1945, located in the Owl Mountains in Lower Silesia - Poland (Fig. 4). Because of their geological structure (hard gneiss rock) and the difficult topographical access, it is sure that locating an object of such strategic importance in this area was not accidental [2]. Moreover, before the war Wałbrzych region was heavily industrialized - the area was developed in roads, telecommunications network and other necessary

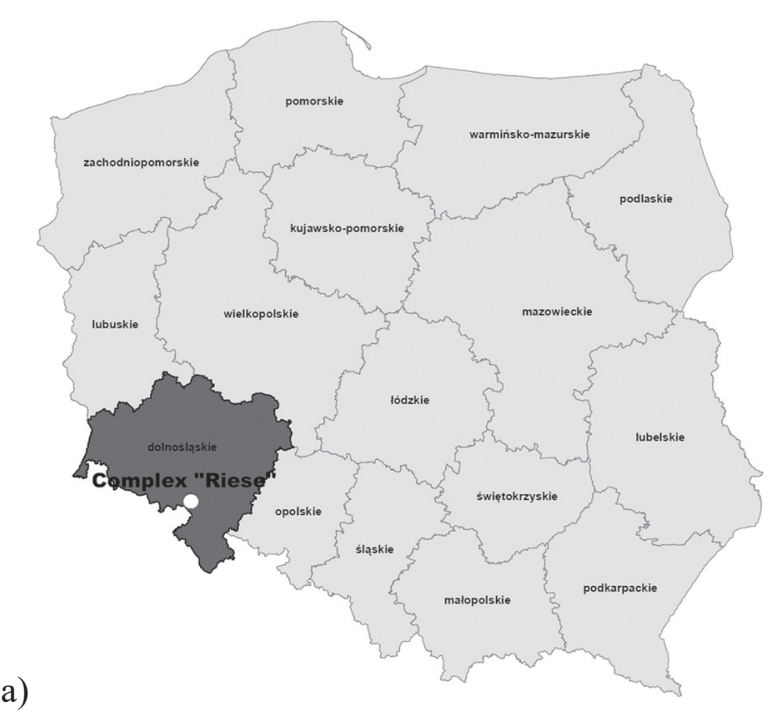

b)

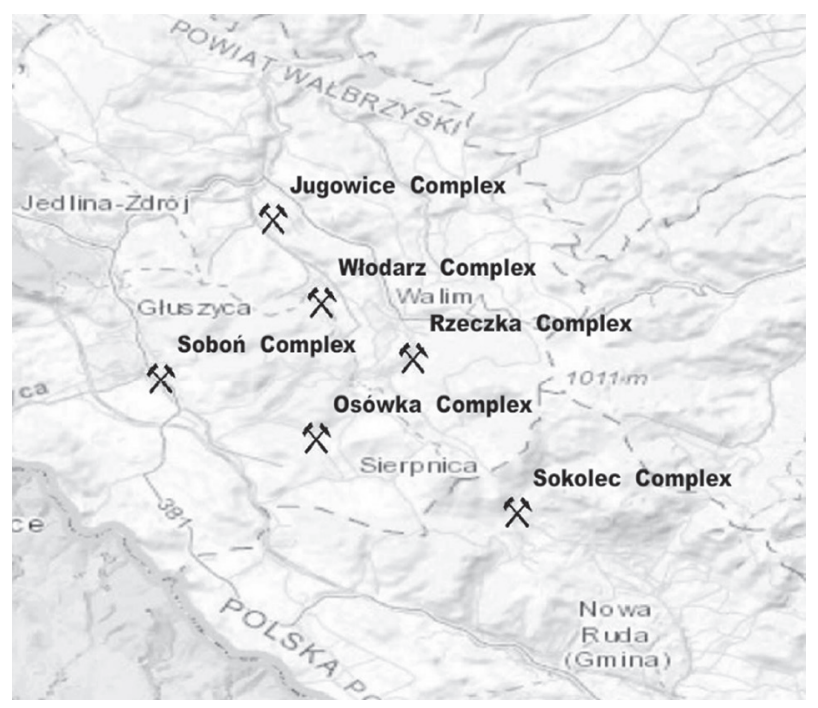

Fig. 4. Localization of: a) Riese Complex in Poland, b) each of complexes in Riese area

Rys. 4. Lokalizacja: a) Kompleksu Riese w Polsce, b) każdego z kompleksów na obszarze Riese 
Table 1. Dimensions of inventoried complexes

Tabela 1. Wymiary zinwentaryzowanych kompleksów

\begin{tabular}{|l|c|c|c|}
\hline \multicolumn{1}{|c|}{ Complex } & Total length of drifts $[\mathbf{m}]$ & Area $\left[\mathbf{m}^{2}\right]$ & Volume [thousand $\mathbf{~ m}^{3}$ ] \\
\hline Osówka & 1743 & 6680 & 28 \\
\hline Sztotnia Wodna ('Water Adit') & 144 & 366 & 0,8 \\
\hline Soboń & 572 & 1486 & 3,6 \\
\hline Rzeczka & 532 & 2575 & 14,1 \\
\hline Jugowice & 387 & 1266 & 3,6 \\
\hline
\end{tabular}

devices for running a large-scale undertaking. However, because of the lack of the documentation and lack of witnesses, the purpose of building the complex is still uncertain. It is known that the construction work was done by forced labourers and prisoners of concentration camp Gross-Rosen. Drilling the corridors of the acids in hard gneiss rock mass cost many lives.

Until today, there have been six adits discovered in the area of Walim and Głuszyca (Fig. 4): Włodarz, Osówka, Sokolec, Soboń, Rzeczka, Jugowice and tunnels under Książ Castle in Walbrzych. Underground excavations are spaced apart from 1 to $4 \mathrm{~km}$. During the researchers, it turned out that many of the tunnels in some structures have a dead end. Therefore, it is possible that all complexes were connected in one large underground "city". There is a belief that many kilometers of tunnels are still undiscovered [4].

From 2015, inventory measurements have been carried out and collected which allowed acquiring a huge amount of data for analysis and visualization of underground complex. The measurements were carried out both in open adits or partially accessible for tourism (Osówka, Rzeczka, the Książ Castle underground) as well as inaccessible for tourists (Jugowice, Soboń). During measurements, the combination of classical geodetic measurements technologies and modern surveys methods were used - terrestrial laser scanner, tachymetry and GNSS measurements. Due to the number of inventoried underground complexes, the field works were conducted in several periods. Before the measurements at each of the complexes, the field interview of the objects and their surroundings was necessary. At that time, the arrangement of laser scanner positions and the locations for static GNSS measurements were planned.

Materials acquired during measurement were used to carry out a number of analyses. The main purpose of the inventory surveys was to create three-dimensional

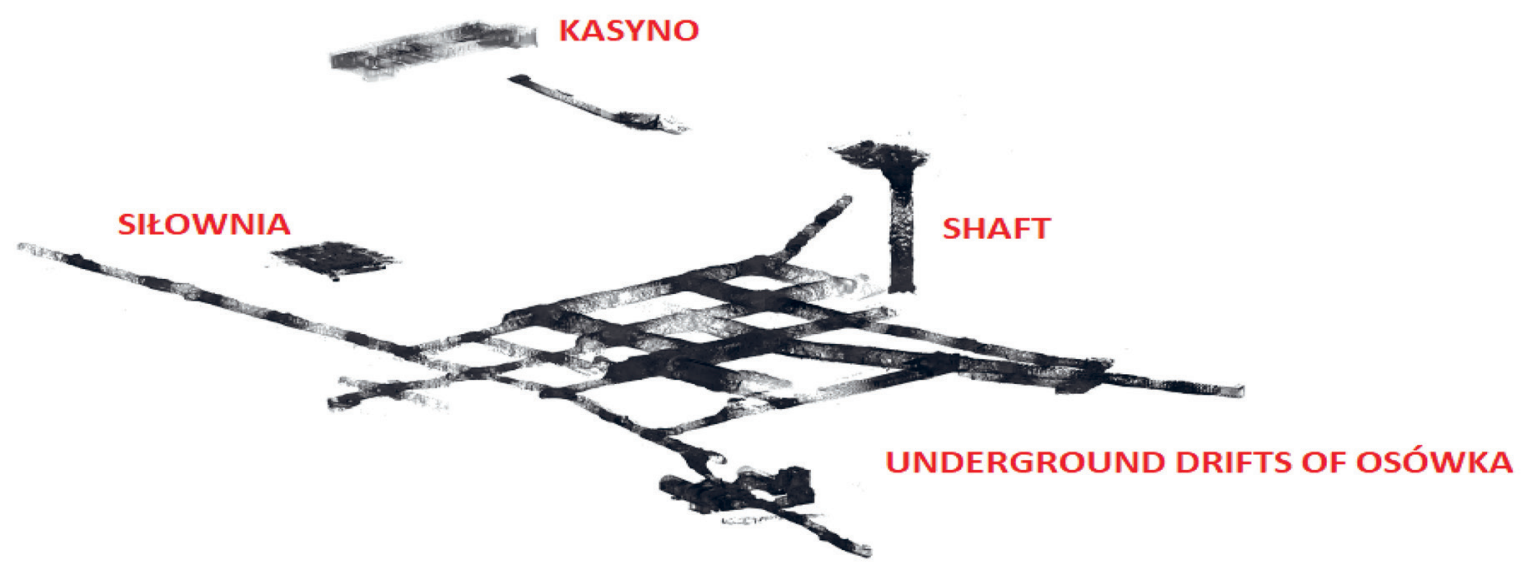

Fig. 5. Spatial distribution of the Osówka's components

Rys. 5. Przestrzenne przemieszczenie obiektów wchodzących w skład "Osówki” 

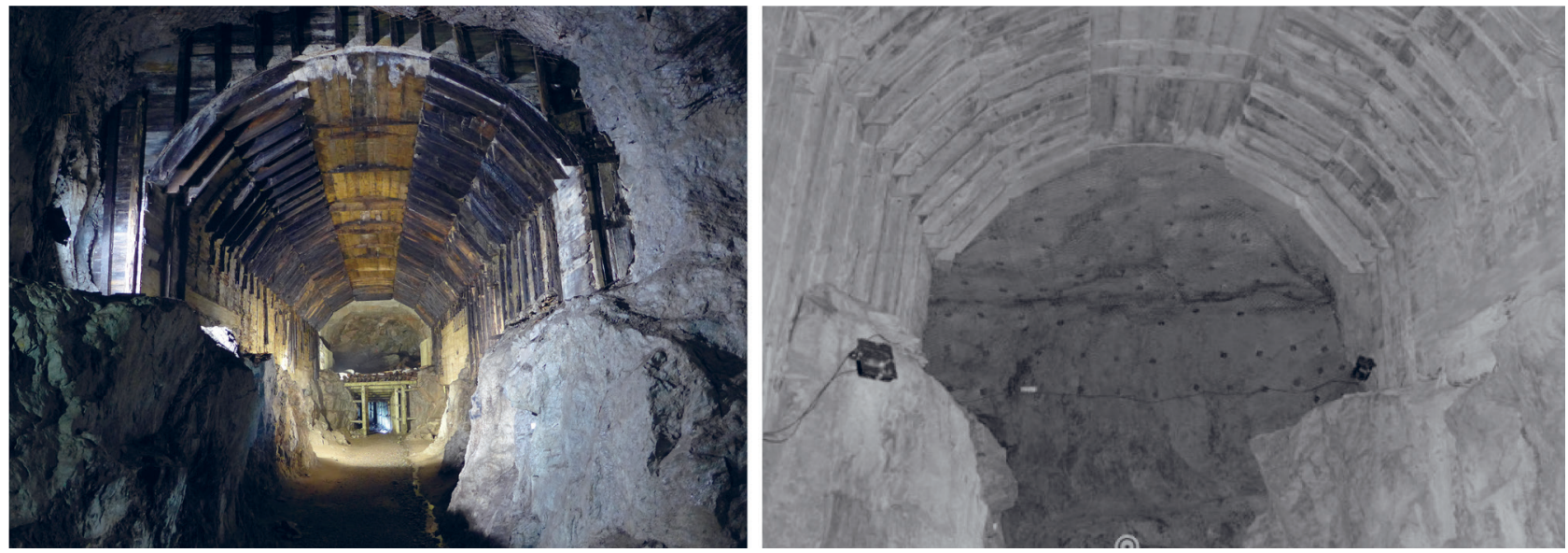

Fig. 6. Great Hall in Osówka Complex (current view on the left and scan on the right)

Rys. 6. Wielka Hala w kompleksie Osówka (aktualny widok po lewej, widok skanu po prawej)

models based on spatial points from terrestrial laser scanning. Technology of terrestrial laser scanning let mainly to perform analysis in CAD and GIS environment. A comprehensive inventory of the most important objects of the entire complex were made. At first, dimensions, volumes and areas of excavations and analyse the length of drifts in the complexes were calculated (table 1).

The underground systems and dimensions of individual adits differ significantly from each other. The Osówka complex (the 'heart' of the Riese complex) is the most advanced object in development [8]. Figure 5 and 6 show the spatial distribution of the Osówka's components (both underground and terrestrial) and the view of the biggest part of the complex - Great Hall $(6 \mathrm{~m} \times 20 \mathrm{~m} \times 7 \mathrm{~m})$. A distinctive element of Great Hall is the leftover formwork.

Additionally, based on topographic maps from different periods and current airborne laser scanning data, spatial terrain models were created, thanks to which it was possible to determine, among others, detailed heights of entrances to individual complexes. The attempt to determine whether the hypothesis about the connection between complexes is true. Figure 7 and 8 an example of registered point cloud from measurements of one of the inventoried complexes - Rzeczka, which allowed to create three-dimensional models, sections, profiles, projections and appropriate visualizations.
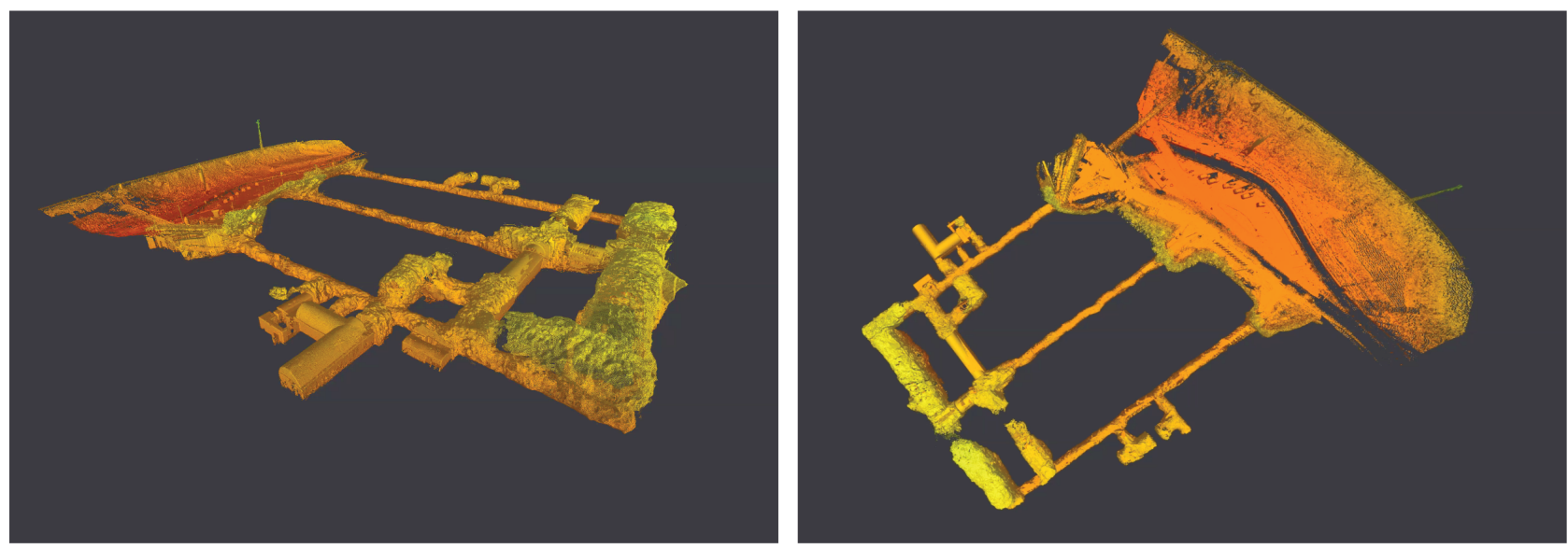

Fig. 7. Point cloud obtained from terrestrial laser scanning measurements of Rzeczka Complex Rys. 7. Chmura punktów kompleksu Rzeczka pochodząca z naziemnego skaningu laserowego 


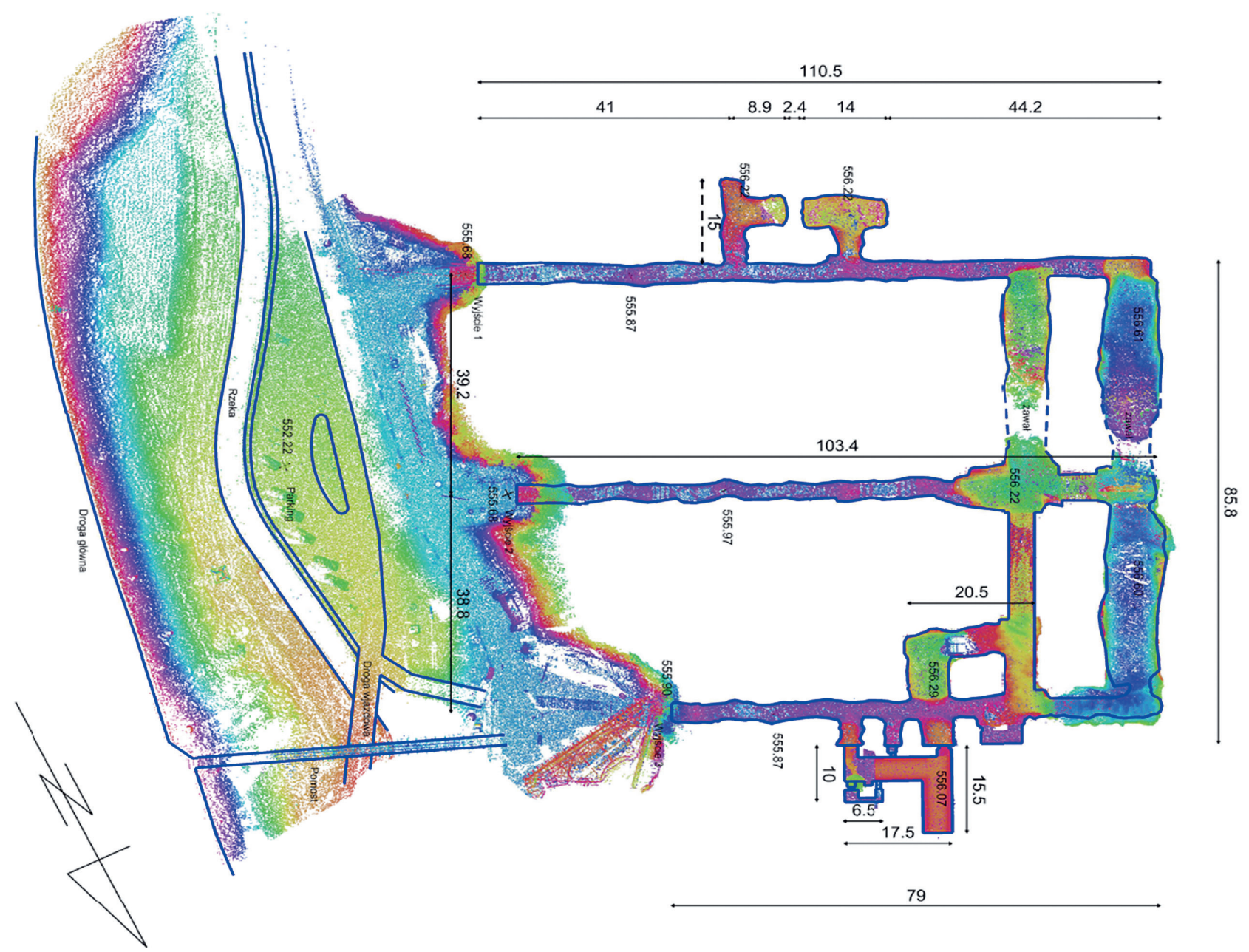

Fig. 8. Visualization of Rzeczka Complex - projection of the underground drifts

Rys. 8. Wizualizacja Kompleksu Rzeczka - rzut podziemnych korytarzy

\section{CONCLUSION}

Determining the stability of the underground object is crucial for security. A special attention should be paid to the historical buildings, which are more and more often made available to tourists. An important aspect of the inventory of objects is the ongoing determination of changes that threaten the objects and tourists themselves. The scope of measurements and required accuracy should be developed before special measurements are made. They should be adjusted to the scale of the occurring phenomenon and forecasted changes, if such forecasts were developed. The frequency of the measurement series should also be adjusted.

The completed research and surveys of Riese Complex has depicted the versatility of laser scanning tech- nology (both terrestrial and aerial) and usage of Global Navigation Satellite System in inventory of underground historical objects. Georeferenced objects and their precise positioning between each other has given answers to many questions and opened the way for further researches. As indicated in the article, accurate geodetic data can be useful for historians, geophysicists and geologists.

\section{ACKNOWLEDGEMENTS}

The research was carried out as part of the activities of the Scientific Circle "KNGK Geoinformatyka" (AGH University of Science and Technology) and students and employees of the Mining Area Protection, Geoinformation and Mining Surveying Faculty. 


\section{REFERENCES}

[1] A. Affek, Airborne laser scanning (ALS) in terrain modelling - new opportunities and pitfalls, PEK, T. XXXVIII, 217-236, 2014.

[2] Aniszewski M., Underground world of Owl Mountains (Podziemny świat Gór Sowich), Oficyna Wydawnicza Aniszewski, Kraków 2002.

[3] Bartos M., Chmura J., Wieja T., Organizational, design and technology issues in the process of protection of underground historic monuments, Civil And Environmental Engineering Reports, vol. 17, pp. 5-14, 2015.

[4] Cera J., Mysteries of Owl Mountains (Tajemnice Gór Sowich), AURH Inter Cera, Kraków, 1998.

[5] Faltýnová M., Nový P., Airborne laser scanning and image processing techniques for archaeological prospection, The International Archives of the Photogrammetry, Remote Sensing and Spatial Information Sciences, Volume XL-5, Italy, 2014.

[6] Hejmanowska B., Borowiec N., Badurska M., 2008: Airborne LIDAR data processing for digital surface model and digital terrain model generation, Archiwum Fotogrametrii, Kartografii i Teledetekcji, Vol. 18, p. 151-162.

[7] Jabłoński M., Jaśkowski W., Lipecki T., Telemetry measurements of shaft tube influenced by sealing of the housing, Geodesy and mine surveying (SGEM), vol. 17, iss. 22, pp. $577-584$.

[8] Jabłoński M., Lipecki T., Jaśkowski W., Ochałek A., Virtual Underground City Osówka, Geology, Geophysics and Environment, vol. 42, no. 1, 77-78, Slovakia, 2016.

[9] Lipecki T., Jaśkowski W., Gruszczyński W., Matwij K., Matwij W., Ulmaniec P., Inventory of the geometric condition of inanimate nature reserve Crystal Caves in "Wieliczka" 'Salt Mine, Acta Geodaetica et Geophysica, Hungarica, vol. 51, no. 2, pp. 257-272, 2016.
[10] Lipecki T., Jaśkowski W., The accuracy of determination of the gyroscopic azimuth by means of the GYROMAT 2000 instrument, in condition of Polish underground mines, Przegląd Górniczy, vol. 67, no. 12, pp. 23-28, 2011.

[11] Lipecki T., Vertical Displacement of the Surface Area over the Leakage to the Transverse salt Mina in 1992-2012, E3S Web of Conference 35, POL-VIET 2017, Poland, 2018.

[12] Maciaszek J., Madusiok D., Matwij W., The comparison of the results of laser scanning and classical surveying methods of measuring the area and volume in the chapel of St. Kinga in the s alt mine of Bochnia, Geology, Geophysics \& Environment, vol. 39, no. 3, pp. 211-221, 2013.

[13] Porzucek S., Underground gravity survey for exploration unknown galleries, Surveying Geology and Mining Ecology Management (SGEM), pp. 637-644. Sofia, Bułgaria, 2017.

[14] Porzucek S., Loosenings and cracks detection in rock mass located above anthropogenic voids using the microgravimetry method (Wykrywanie rozluźnień i spękań górotworu nad pustkami antropogenicznymi metoda mikrograwimetryczna), Wydawnictwa AGH, Kraków, pp. 97-111 (in Polish), 2013.

[15] Szafarczyk A., Gawałkiewicz R., Defining the Cubature Changes of Historic St. Kinga Chamber in Bochnia Salt Mine, Using Laser Scanning Technology, E3S Web of Conferences 35, POL-VIET 2017, Poland, 2018.

[16] Szczerbowski Z., Kaczorowski M,. Wiewiórka J., Jóźwik M., Zdunek R., Kawalec A., Monitoring of tectonically active area of Bochnia, Acta Geodyn. Geomater., vol. 13, no. 1 (181), pp. 59-67, 2016.

[17] Żelaźniewicz, A., Aleksandrowski, P., Tectonic subdivision of Poland: southwestern Poland. Przegląd Geologiczny, vol. 56, pp. 904-911, 2008. 